\title{
The effect of Staking and Plant Spacing on the growth and yield of Cucumber (Cucumis Sativus L.)
}

\author{
Nweke, I.A.* Orji E.C.*Ijearu, S.I** \\ *Faculty of Agriculture, Anambra State University, Igbariam Campus, Anambra state, Nigeria. \\ **Department of Agricultural Education, Institute of Ecumenical Education Thinker's Corner Enugu \\ state, Nigeria.
}

\begin{abstract}
This study was conducted in Thinker's Corner-Emene Enugu, Southeastern Nigeria to determine the effect of staking and plant spacing on the growth and yield of cucumber. Staked and unstaked and three plant spacing $(50 \mathrm{~cm} \times 30 \mathrm{~cm}, 50 \mathrm{~cm} \times 40 \mathrm{~cm}$ and $50 \mathrm{~cm} \times 50 \mathrm{~cm})$ were evaluated. The study was conducted as a $2 \times 3$ factorial laid out in randomized complete block design $(R C B D)$ with five replications. Treatment means were separated using least significant difference ( $L S D=0.05)$. The result generated from the study showed that number of fruits, number of marketable fruits and weight of fruits. Staking had no significant effect on weight of fruits, but showed significant effect on number of branches, number of leaves and vine length decreased as the plant spacing increased from $50 \mathrm{~cm} \times 30 \mathrm{~cm}$ to $50 \mathrm{~cm} \times 40 \mathrm{~cm}$. The closest plant spacing $(50 \mathrm{~cm} \times 30 \mathrm{~cm})$ recorded the highest value in all the parameters assessed in this trial except for number of flowers, Days to 50\% anthesis, length of fruit and weight of fruit. The staked treatment constantly performed better with higher values than the non-staked treatment except for the flowers and number of non-marketable fruits. Hence for maximum production of cucumber staking and closer plant spacing should be adopted.
\end{abstract}

Keywords: Staking, Plant spacing, Cucumber, Growth, Yield, Soil, Thinker's Corner.

\section{Introduction.}

Cucumber production in most part of Nigeria is fast becoming popular, probable due to its high nutritional and medicinal values, as well as being a useful component ingredient in the canteens preparation of salad and liquor drink in hotels and homes. Cucumber is good for diabetic patients as it contains low sugar and help in the burning of excess fat in the body. The outer covering that is melanin or the epicarp of cucumber is used or mixed with pomade or cream to control oily or fatty face. In spite of all these wonderful attributes of cucumber, the production of the crop is still mainly in the hands of peasant farmers in Nigeria who lack information in some important cultural practices such as staking and right spacing for optimum yield of the crop. These farmers allow the vines to trail on the ground leading to the production of fruits with yellow bellies, over crowding of the vines and subsequent attack by mould due to high humidity. Studies has shown that cucumber appropriately spaced and staked show enormous disparity and difference with the both unstaked and unspaced, as a result of avoiding competition, overcrowding and correct exposure or positioning of cucumber leaves to sunlight for effective photosynthetic activities, that will enhance fruit yield. Elsewhere, staking of cucumber has been found to help optimize yields for harvest of pickling cucumber. Higher fruit yield was observed on trellis treatment than for the non-trellised treatment (Hardy and Rowell, (2002); Hirata and Tilato (2000) also Nelson, (2005) and Paulo et al; (2003) reported increases in fruit yield as plant density increased.

The present study investigated the effect of plant spacing and staking on the growth and yield of cucumber grown in Southeastern Nigeria.

\section{Site location}

\section{Materials and Methods}

The field experiment was conducted on the experimental farm of Agricultural Education, Institute of Ecumenical Education Thinker's Corner Emene Enugu $\left(06^{\circ} 48^{1} \mathrm{~N}\right.$ and $\left.07^{\circ} 14^{1} \mathrm{E}\right)$, Nigeria. The rainfall pattern is bimodal between April and October, while dry season is between November and March. The annual rainfall ranged between $1200 \mathrm{~mm}-1750 \mathrm{~mm}$. The soil of the experimental site is classified as Ultisol (FDALR, 1985).

\section{Land preparation and soil sampling.}

The experimental field was cleared of its natural weeds, the debris burnt and the field bedded was divided into plots $(3 \mathrm{mx} 4 \mathrm{~m})$. Before planting a representative soil samples was taken with an auger at different parts of the field and were thoroughly mixed together to form a composite sample which was air dried and made to pass through a $2 \mathrm{~mm}$ and $0.5 \mathrm{~mm}$ sieve for particle size and chemical analysis. The result of the Physicochemical characteristics of the soils of the experimental site is given in Table 1. 
Table 1 Physical and Chemical properties of Soils of the experimental

\begin{tabular}{|c|c|c|}
\hline Parameter & Unit & Value \\
\hline Sand & $\%$ & 55 \\
\hline Salt & $\%$ & 35 \\
\hline Clay & $\%$ & 10 \\
\hline Texture & $\%$ & Sandy loam \\
\hline $\mathrm{PH}\left(\mathrm{H}_{2} \mathrm{O}\right)$ & & 4.60 \\
\hline Total N & $\%$ & 0.05 \\
\hline $\mathrm{OM}$ & $\%$ & 1.15 \\
\hline $\mathrm{Ca}$ & Cmolkg ${ }^{-1}$ & 1.6 \\
\hline $\mathrm{Mg}$ & Cmolkg ${ }^{-1}$ & 1.5 \\
\hline $\mathrm{Na}$ & Cmolkg-1 & 0.18 \\
\hline $\mathrm{Kg}$ & Cmolkg ${ }^{-1}$ & 0.07 \\
\hline E CEC & Cmolkg ${ }^{-1}$ & 12.8 \\
\hline Avail. P & $\mathrm{Mgkg}^{-1}$ & 3.7 \\
\hline Ex.. Acidity & $\mathrm{Cmolkg}^{-1}$ & 4.00 \\
\hline
\end{tabular}

\section{Experimental design.}

The experiment was conducted as $2 \times 3$ factorial laid out in a Randomized complete block design (RCBD) with five replications. Two staking (staked, un staked) and three-plant spacing $(50 \mathrm{~cm} \times 30 \mathrm{~cm}$; $50 \mathrm{~cm} \times 40 \mathrm{~cm}$ and $50 \mathrm{~cm} \times 50 \mathrm{~cm}$ ) were the treatments used. Two seeds of cucumber were planted two per hole at a depth of about $2 \mathrm{~cm}$ and later thinned down to one plant per stand two weeks after germination. NPK fertilizer at the rate of $100 \mathrm{~kg}$ NPK/ha was applied as a blanket treatment to all the plots, using broadcasting method two weeks after germination. Weeds were manually controlled and the crop and the crop was sprayed with wood ash at $5^{\text {th }}$ and $6^{\text {th }}$ week after planting to protect the crop against cucumber beetle, Zonocerus variegates and lady beetle identified in the locality. Parameters evaluated were number of branches, number of leaves, leaf area, vine length, number of flowers, Days to 50\% flowering (Anthesis), number of fruit, length of fruit, number of non-marketable fruit, number of marketable fruit and weight of fruit. All data generated during the experiment were subjected to statistical analysis using the procedure outlined by Steel and Torrie (1980) for a factorial experiment in Randomized complete Block Design (RCBD) and the means were separated by the least significance difference (LSD) at 5\% alpha level.

\section{Results}

The staked cucumber plants produced more number of leaves than the un staked treatment and they were statistically similar (Table 2) showing that staking treatments has no significant effect on the number of leaves. The table also shows that the number of leaves was not significantly affected by plant spacing. Though the number of leaves decreased as plant spacing increased from $50 \mathrm{~cm} \times 30 \mathrm{~cm}$ to $50 \mathrm{cmx} 40 \mathrm{~cm}$, but increased in $50 \mathrm{~cm} \times 50 \mathrm{~cm}$, the least value was recorded in $50 \mathrm{~cm} \times 40 \mathrm{~cm}$, while the closest plant spacing $(50 \mathrm{~cm} \times 30 \mathrm{~cm})$ produced the highest number of leaves.

The leaf area (Table 2) value in staked cucumber was found to be higher than the un staked plants. The value decreased as the plant spacing increased.

Table 2 Effect of Staking and Plant spacing on the number of leaves and leaf area

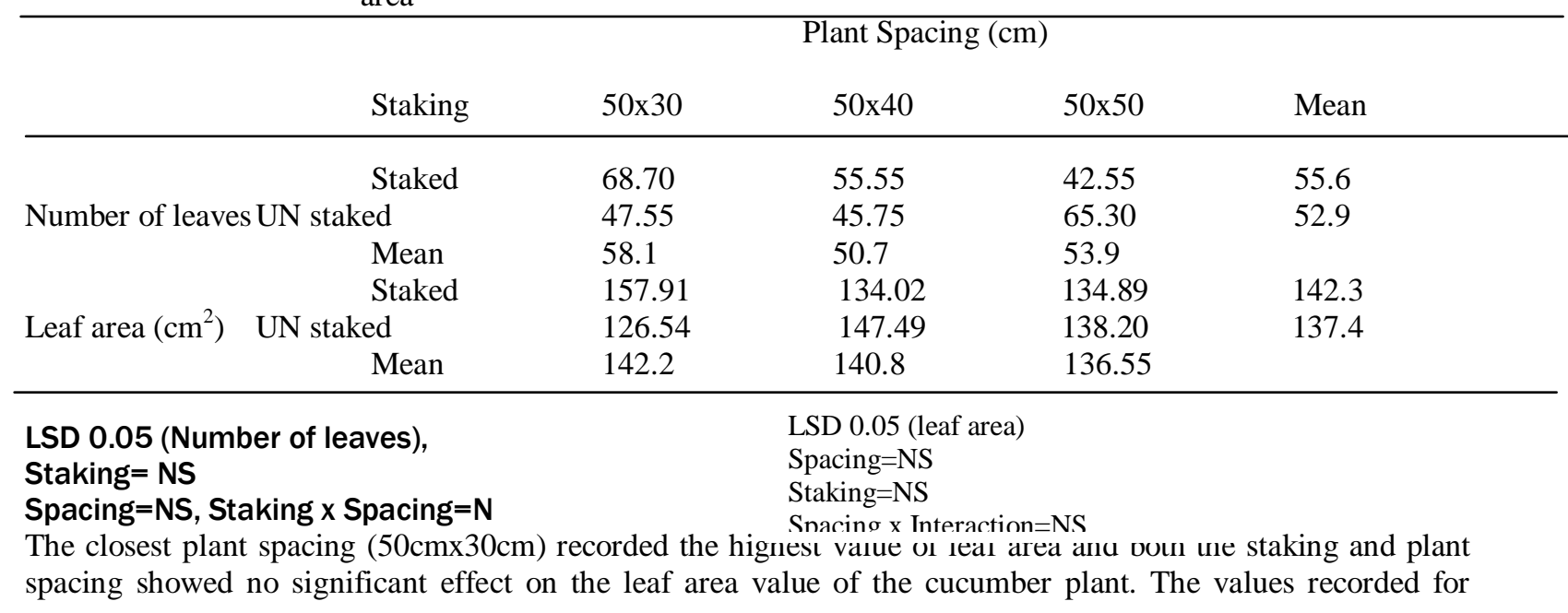


number of branches, vine length, number of flowers and days to $50 \%$ flowering showed that staking and plant spacing treatment have no significant effect on all these parameters assessed. However, the result (Table 3) showed that higher values are recorded in staked plants than the un staked ones. The effect of plant spacing however does not follow this trends, the number of branches and vine length decreased in $50 \mathrm{~cm} \times 40 \mathrm{~cm}$ spacing and increased in $50 \mathrm{~cm} \times 50 \mathrm{~cm}$ plant spacing.

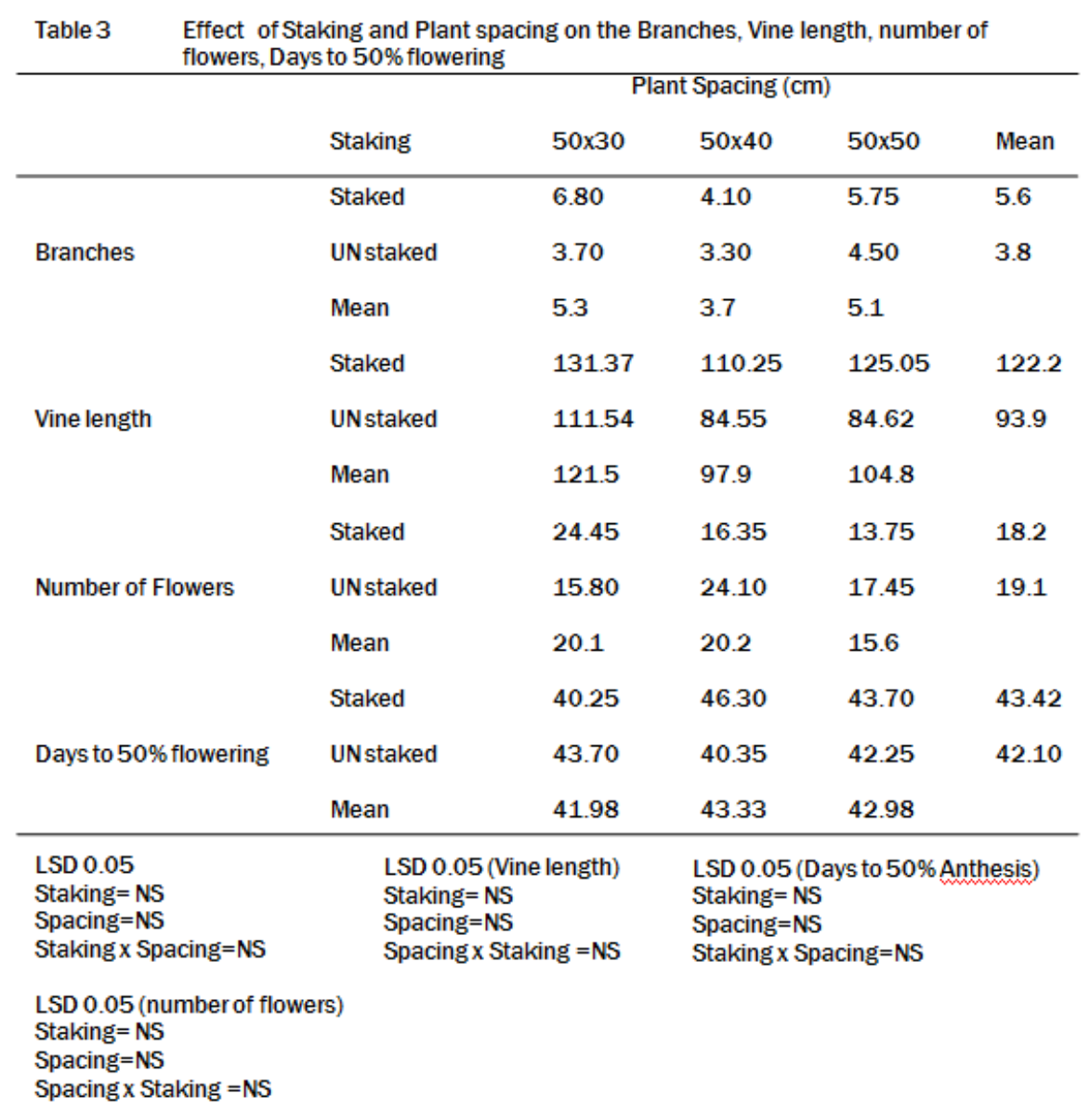

The number of flowers and 50\% flowers increased as plant spacing increased but decreased in the widest space, $50 \mathrm{~cm} \times 50 \mathrm{~cm}$. The result of number of fruit, length of fruit, weight of fruit, number of non-marketable fruit and marketable fruit presented in table 4 showed that staked plants produced higher values than the un staked plants except in weight of fruit where their fruit yield are equal and in non-marketable fruit, where staked value is less than un staked. Table 4 also showed that staking has significant $(\mathrm{p}=0.05)$ effect on the number of fruit and number of marketable fruit but showed no effect on length of fruit, number of non-marketable fruit, and weight of fruit. The value recorded for number of fruit, number of non-marketable fruit and number of marketable fruits decreased as plant spacing increased. The widest plant spacing produced the least value in number of fruit, nonmarketable and marketable fruit. The plant spacing of $50 \mathrm{~cm} \times 40 \mathrm{~cm}$ produced the highest length of fruit and fruit weight. Also significant differences between plant spacing was observed in the number of fruits and staking $\mathrm{x}$ spacing interaction was significant at $\mathrm{P}=0.05$. However, the value obtained in $50 \mathrm{~cm} \times 40 \mathrm{~cm}$ and $50 \mathrm{~cm} \times 50 \mathrm{~cm}$ spacing was statistically similar. 
Table 4 Length of fruit, marketable fruit, non-marketable fruit and weight of fruit.

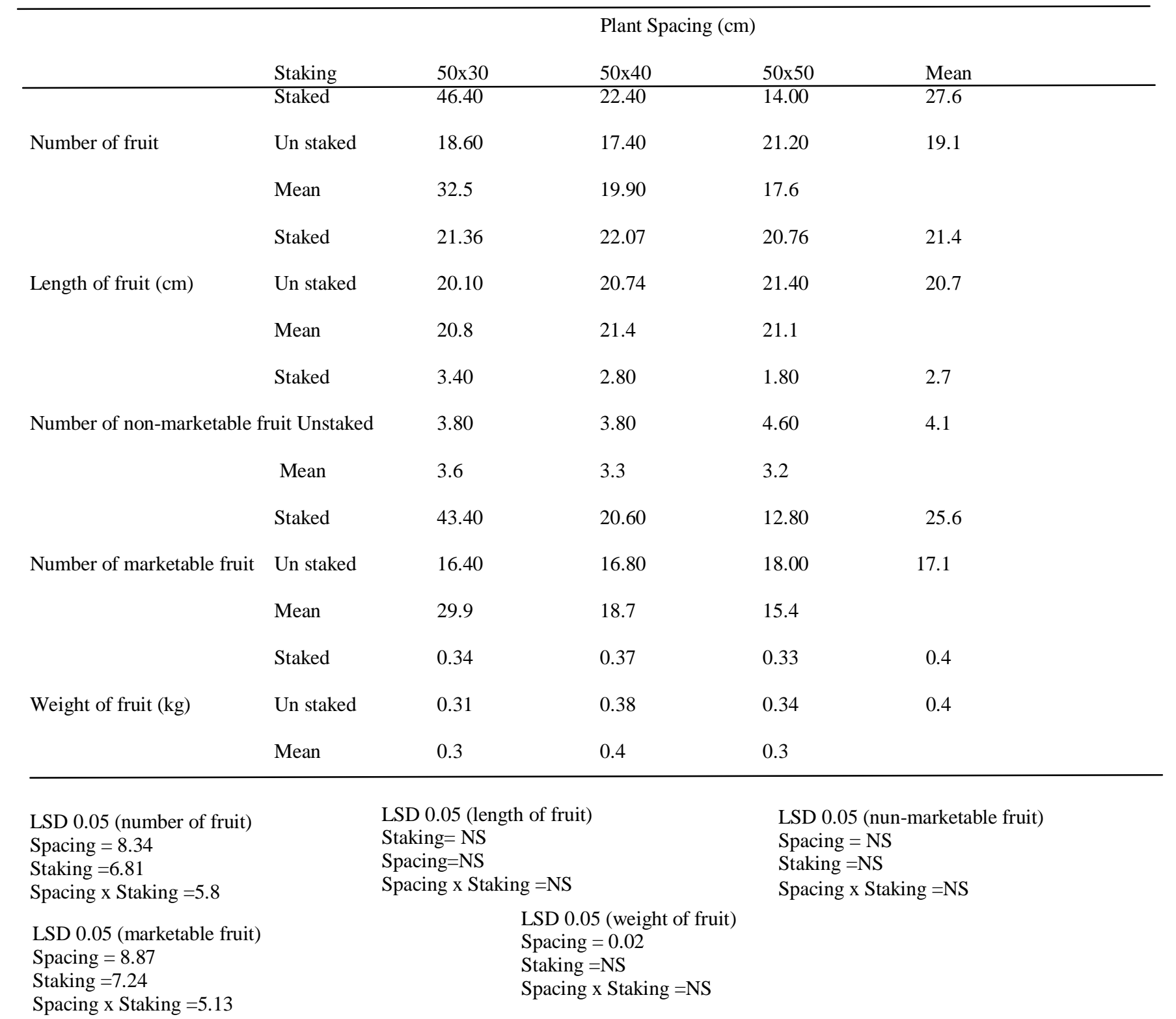


The result of number of marketable fruit also showed significant differences among the treatments in both staking and plant spacing treatments (table 4) and staking $\mathrm{x}$ plant spacing interaction was equally significant at $\mathrm{P}=0.05$. The effect of $50 \mathrm{~cm} \times 40 \mathrm{~cm}$ and $50 \mathrm{~cm} \times 50 \mathrm{~cm}$ spacing was similar. Staking treatment had no significant effect on the weight of fruit, while plant spacing showed significant effect on the weight of fruit, however the effect of the closest $(50 \mathrm{~cm} \times 30 \mathrm{~cm})$ and widest $(50 \mathrm{~cm} \times 50 \mathrm{~cm}$ plant spacing were statistically similar and their interaction (staking x plant spacing) had no significant effect on the weight of fruit (Table 4).

\section{Discussion.}

\section{Effect of staking and plant spacing on the vegetative growth of cucumber.}

The result of this field trial showed that staking and plant spacing had effect on the vegetative growth of cucumber, although all the parameters measured for vegetative growth were non-significant at $\mathrm{P}=0.05$. The number of Leaves, Branches, and Vine length decreased as the plant spacing increased from $50 \mathrm{~cm} \times 30 \mathrm{~cm}$ to $50 \mathrm{~cm} \times 40 \mathrm{~cm}$ but not beyond $50 \mathrm{~cm} \times 40 \mathrm{~cm}$. There was also a decrease in leaf area as the plant spacing increased from $50 \mathrm{~cm} \times 30 \mathrm{~cm}$ to $50 \mathrm{~cm} \times 50 \mathrm{~cm}$. The closest plant spacing $50 \mathrm{~cm} \times 30 \mathrm{~cm}$ produced the highest number of branches, leaves, and leaf area and vine length. The number of branches, number of leaves, vine length and leaf area were higher in the staked than the non-staked treatment. This may suggest that the leaves on the staked plants were all exposed to greater light interception leading to a higher accumulation of photosynthesis for vegetative growth.

Hanna and Adams (1991) reported that staking cucumber increased the fruit yield because of better light interception. The number of days to 50\% anthesis was higher in the staked than the non-staked treatment. This agrees with the findings of Jansen, (1985) who observed that staking prolongs vegetative growth and delays fruit formation. The non-staked treatment consistently produced lower values in all the vegetative parameters evaluated except in the number of flowers.

\section{Effect of staking and plant spacing on the yield of cucumber.}

The closest plant spacing $(50 \mathrm{~cm} \times 30 \mathrm{~cm})$ produced the highest number of fruit, number of marketable and non-marketable fruits, while length of fruit and weight of fruit was highest at $50 \mathrm{cmx} 40 \mathrm{~cm}$. Gebologu and Saglam (1999), reported highest fruit yield in $20 \mathrm{~cm}$, the closest plant spacing used. While Quian (2000) observed that the closest plant spacing gave the highest early yield. Also Jacques et al; (2002) reported that the number of fruit decreased as the plant density changed from four to ten plants per meter square. However the observations made in the trial is contrary to the findings of Jonathan et al (1996), Phamthic (1991) and Paulo et al (2003) who obtained highest yield at higher plant spacing. The yield parameters assessed were found to be higher on the staked plants than that vine on the ground. The result agreed with the findings of Hardy and Rowell (2002) who observed that the yield of super select cucumbers were higher for the trellised treatment than for the non-trellised treatment. Hanna and Adams (1991) reported that staked cucumber gave an average marketable yield of 25 ton/acre as against 16.4 tons/acre of the non-staked cucumber. While Jansen (1985) concluded that staked cucumber produced fruits that double the quantity of the ones on the ground. The number of non-marketable fruit was higher in the non-staked than the staked treatment. This could be attributed to the poor quality in the color of the fruit, reduced length of fruit and development of yellow bellies on the fruits, which predisposes them to spoilage. Hanna and Adams (1991) reported that staking brings about an increase in color quality, fruit length and sugar content of the fruits. Also Hardy and Rowell et al, (2002) affirmed that staking improves the color and lower the incidence of yellow bellies in cucumber. The non-staked treatment consistently gave least values in all the yield parameters evaluated except in the number of non-marketable fruits.

\section{Conclusion:}

The result showed that staking and plant spacing treatment had effect on the vegetative growth and yield of cucumber. The non-staked treatment consistently gave least values in all the vegetative and yield parameters measured except in the number of flowers and number of non-marketable fruits respectively, while the closest plants spacing produced highest values virtually in all the parameters assessed in this trial. The result, therefore, suggest that the vegetable farmers who have the intention of producing high quality cucumber fruit from the Agro-ecological zone understudy should adopt staking and use a plant spacing of $50 \mathrm{~cm} \times 30 \mathrm{~cm}$ for maximum production.

\section{References:}

[1]. Federal Department of Agriculture and land Resources (1985). Reconnaissance soil survey of Anambra state. Nigeria soils report, FDALR Kaduna

[2]. Gebologu, N and Saglam.R.(1999). The effect of different of different spacing and mulching materials on the yield and fruit quality of pickling cucumber. Acta Horticulture 579:11 Balkam symposium on vegetable and potatoe.

[3]. Hardy, C. and Rowell, B. (2002). Trellising slicing cucumber in Western Kenturcky Hort bulletin Vol.3 PP 15-18 
[4]. Hanna H.Y and Adams A.J. (1991). Staking fresh market cucumber gives higher yields. A long term Research report pro-society 104: 237-240.

[5]. Hirata, S.L. and Tilato, R. (2002). Comparative cost of Teepee-Trellised Vs Non-trellised cucumber production. Economic information report EL 95-1 PP 40-46.

[6]. Jacques, L.S., Jeronimo, L.A. and Aron, B.H, (2002). Dry matter accumulation and partitioning of pickling cucumber plants under different plants densities. Clientia Rural, Santa Maria, Vol.32(1):3-41.

[7]. Jansen,D.Y. (1985). Trellised cukes yield more cucumbers. Hortbulletin Vol.5 PP 13-18.

[8]. Jonathan, R.Schlthesis and Todd.C.Wehner, (1996) Optimum density of determinate and normal pickling cucumbers harvested once over. Hort. Sci. 10 (3): 151-155.

[9]. Nelson, H., (2005). Effect of Population density on fruits and seeds production in muskmelon Acta Horticulture 38(3): 15-28.

[10]. Paulo, S. Lima, S., Jailton, F.R., Jaedson, C.A.M, and Jaeverson D.A.S., (2003). Plant density and fruit density of muskmelon. Rer. Bras frutic Vol.25, No.2. Jaboticabal..

[11]. Phamthic Kin Thu (1991). Effect of spacing and pruning on the yield of cucumber. Hort. Sci. 36(2): 230-235.

[12]. Quian, H. (2000). Effect of pruning and spacing on yield and quality of cucumber. Hort. Sci. 36(2): 274-278.

[13]. Steel, R.G.D. and Torrie, J.H. (1980). Principles and procedures of statistics. A biometrical approach $2^{\text {nd }}$ edn., McGraw Hill book Co. Inc. New York PP 633. 